\title{
Exaggerated Response of Renin Secretion to Captopril (SQ 14225) in Renovascular Hypertension
}

\author{
Yutaka Imar, M.D., Keishi Abe, M.D., Yoichi Otsuka, M.D., \\ Yutaka Sakurai, M.D., Toru Ito, M.D., Makito SAto, M.D., \\ Toshiaki Haruyama, M.D., Ken Omata, M.D., \\ Masao Hiwatari, M.D., and Kaoru Yoshinaga, M.D.
}

\begin{abstract}
SUMmary
Captopril (SQ 14225), an orally active converting enzyme inhibitor, was administered in a dose of $50 \mathrm{mg}$ to 12 normotensive subjects (Group I), 26 essential hypertensive patients (Group II), and 8 renovascular hypertensive patients (Group III). In Group III, 5 of the 8 patients had control plasma renin activity (PRA) similar to those in Groups I and II patients, but the PRA response to the administration of captopril was greater in 7 of the 8 patients than those in Groups I and II. These 7 patients had either bilateral or unilateral main renal artery stenosis. Captopril caused no increase in PRA in the remaining 1 who had unilateral renal artery stenosis with contralateral renal aplasia.

It is concluded that this provocation test is useful as a screening procedure for the diagnosis of renovascular hypertension.
\end{abstract}

Additional Indexing Words :

Angiotensin I converting enzyme inhibitor Screening test Essential hypertension Cardiovascular response

7 HE determination of plasma renin activity (PRA) before and after 1 provocating maneuvers of renin release such as tilting, ${ }^{11}$ sodium depletion ${ }^{2)}$ or administration of diuretics ${ }^{3)}$ or vasodilators ${ }^{4}$ is useful for diagnosis of renovascular hypertension and predicting the surgical curability. In some patients with renovascular hypertension, however, such maneuvers fail to stimulate the release of renin..$^{5,6)}$

Recently, it has been reported that specific antagonists of angiotensin II or angiotensin I converting enzyme inhibitors (AICEI) augment the PRA. ${ }^{7-9)}$ Re et al $^{10)}$ reported that SQ 20881, an AICEI, enhanced the

From the Department of Internal Medicine, Tohoku University School of Medicine, Sendai, Japan.

This work was supported in part by Research Grants from Japanese Ministry of Education (34320).

Address for reprint: Yutaka Imai, M. D., Department of Internal Medicine, Tohoku University, 1-1, Seiryocho, Sendai 980, Japan.

Received for publication January 23, 1980. 
difference in PRA of the renal vein between the affected side and the intact side in hypertensive patients with unilateral renovascular disease. Gavras

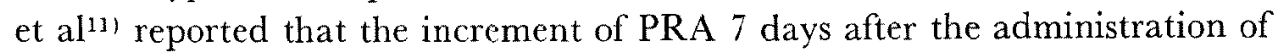
a fixed dose of captopril (SQ 14225), an orally active AICEI, was much greater in patients with renovascular hypertension than in patients with essential hypertension.

The purpose of this study is to examine the response of renin secretion to acute administration of captopril in essential and renovascular hypertension and to see if this provocation test of renin release is useful for the diagnosis of renovascular hypertension.

\section{Materials and Methods}

\section{Patients}

Studies were performed in normotensive subjects (Group I), patients with essential hypertension (Group II), and patients with renovascular hypertension (Group III). Subjects in Group I (12 men), ranging in age from 31 to 51 years, showed no evidence of significant cardiovascular disease, and their mean arterial blood pressures (MAP) ranged from 88 to $105 \mathrm{mmHg}$ at the time of study. Patients in Group II consisted of 8 women and 18 men ranging in age from 32 to 64 years. Routine screening tests for secondary hypertension including intravenous pyelography, ${ }^{131} \mathrm{I}-\mathrm{Hipp} u r a n$ renography, ${ }^{99 \mathrm{~m}}$ Technetium renoscintigraphy, plasma renin activity and plasma aldosterone concentration were performed in all of these patients. As a rule, aortography was performed in Group II to rule out the renal vascular lesion. Details of clinical data in Group III are shown in Table I. The etiological diagnosis of stenotic lesions was tentatively made by angiographic find-

Table I. Clinical Data in Group III Subjects

\begin{tabular}{|c|c|c|c|c|}
\hline $\begin{array}{l}\text { Case } \\
\text { No. }\end{array}$ & $\begin{array}{l}\text { Age } \\
\text { Years }\end{array}$ & Sex & Diagnosis & Drugs and Doses \\
\hline 1. & 62 & Male & Bilateral renal artery stenosis due to AS & None \\
\hline 2. & 48 & Female & Right renal artery stenosis due to FMH & None \\
\hline 3. & 22 & Female & Right renal artery stenosis due to FMH & None \\
\hline 4. & 31 & Female & Left renal artery stenosis due to $\mathrm{FMH}$ & $\mathrm{C}-0.3, \mathrm{~N}-80, \mathrm{~F}-40$ \\
\hline 5. & 49 & Male & $\begin{array}{l}\text { Bilateral renal artery stenosis due to } \\
\text { FMH }\end{array}$ & $\begin{array}{l}\text { C- } 0.15, P-80 \\
N-40, F-40\end{array}$ \\
\hline 6. & 24 & Male & $\begin{array}{l}\text { Bilateral renal artery stenosis due to } \\
\text { FMH }\end{array}$ & $\begin{array}{l}\text { C- } 0.225, \text { P-60, } \\
\text { A-750 }\end{array}$ \\
\hline 7. & 37 & Female & $\begin{array}{l}\text { Right renal artery stenosis due to aortitis } \\
\text { syndrome }\end{array}$ & $\mathrm{P}-60, \mathrm{~T}-4$ \\
\hline 8. & 51 & Male & $\begin{array}{l}\text { Left renal artery stenosis due to AS with } \\
\text { right kidney aplasia }\end{array}$ & $\mathrm{N}-40, \mathrm{P}-40, \mathrm{~T}-2$ \\
\hline
\end{tabular}

Abbreviations : $\mathrm{AS}=$ arteriosclerosis $; \mathrm{FMH}=$ fibromuscular hyperplasia $; \mathrm{C}=$ clonidine $; \mathrm{N}=$ nifedipine; $\mathrm{F}=$ furosemide; $\mathrm{P}=$ propranolol $\mathrm{A}=\alpha$-methyldopa $; \mathrm{T}=$ trichloromethiazide. Dose of each drug is expressed as mg/day. 
ings of the renal artery.

Reconstructive surgery was carried out in 2 instances (Cases 2 and 3). Eight to 14 months after the operation, these patients had diastolic blood pressure of less than $90 \mathrm{mmHg}$ without antihypertensive therapy. Reconstructive surgery was not performed in the other cases: in Case 1 because of bilateral renal artery stenosis due to arteriosclerosis with almost no function of one kidney, in Casc 4 because of the presence of idiopathic thrombocytosis; in Cases 5 and 6 renal arterial lesion due to fibromuscular hyperplasia was extended to intrarenal branches; in Case 7 the renal artery lesion was due to aortitis syndrome; in Case 8 contralateral kidney was nonexistent (aplasia). These patients received medical treatments. Sodium intake was not restricted. All antihypertensive drugs and diuretics were withdrawn for at least 4 weeks prior to the study in all subjects in Group II and Cases 1, 2, and 3 in Group III. Cases 4, 5, 6, 7, and 8 were treated with antihypertensive drugs and diuretics during the course of the study. Details of the drug therapy are given in Table I.

\section{Procedure}

The study was carried out in fasted patients in the morning. The subjects were kept in supine position during the study period. Blood pressure was measured by mercury sphygmomanometer. After at least $30 \mathrm{~min}$ of recumbency, blood pressure and pulse rate were measured every $10 \mathrm{~min}$ for $60 \mathrm{~min}$. At the end of this control period, blood was sampled for the measurement of control PRA, and $50 \mathrm{mg}$ of captopril was then administered orally. Blood pressure and pulse rate were measured every $10 \mathrm{~min}$ for the next 2 hours, and peripheral venous blood sampling was performed 1 hour (SQ1) and 2 hours (SQ2) after the drug administration. Urine sampling during the control period for the measurement of urinary sodium output was performed in some male subjects of each group.

3. Chemistry

PRA was determined using radioimmunoassay of angiotensin I as previously described. ${ }^{12}$ ) Briefly, $1 \mathrm{ml}$ of plasma was incubated at $37^{\circ} \mathrm{C}$ at $\mathrm{pH} 5.5$ for 6 hours with disodium ethylene diamine tetraacetic acid and diisopropyl fluorophosphate. The sample was then diluted 10 fold with physiological saline and heated in a boiling water bath for $5 \mathrm{~min}$. After the centrifugation, angiotensin $I$ in the supernatant was assayed radioimmunologically. This method was approximately 4 times more sensitive than Haber's method. PRA in normal subjects ranged from 5 to $30 \mathrm{ng}$ / ml. ${ }^{13)}$

Statistical analysis was carried out according to Student's $t$-test.

\section{Results}

1. Effects of captopril on PRA in each group

PRA response to captopril in Group $I$ is illustrated in Fig. 1. Control values of PRA in this group ranged from 3.4 to $20.0 \mathrm{ng} / \mathrm{ml}(10.7 \pm 1.1 \mathrm{ng} / \mathrm{ml}$, Mean \pm SE). Mean values of PRA at SQI (1 hour after its administration) and SQ2 (2 hours after its administration) were $15.9 \pm 2.9$ and $19.3 \pm 2.1 \mathrm{ng} /$ $\mathrm{ml}$, respectively. These values were significantly higher than the control value $(\mathrm{p}<0.01)$. PRA response to captopril in Group II is shown in Fig. 2. 


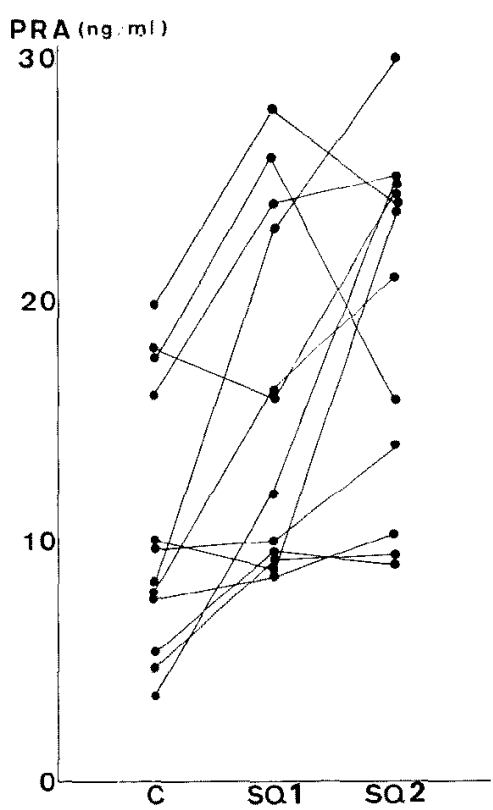

Fig. 1. PRA response to $50 \mathrm{mg}$ of captopril in normotensive subjects. Abbreviations: $\mathrm{C}=$ control; $\mathrm{SQ} 1=1$ hour after captopril administration; $\mathrm{SQ} 2=2$ hours after captopril administration.

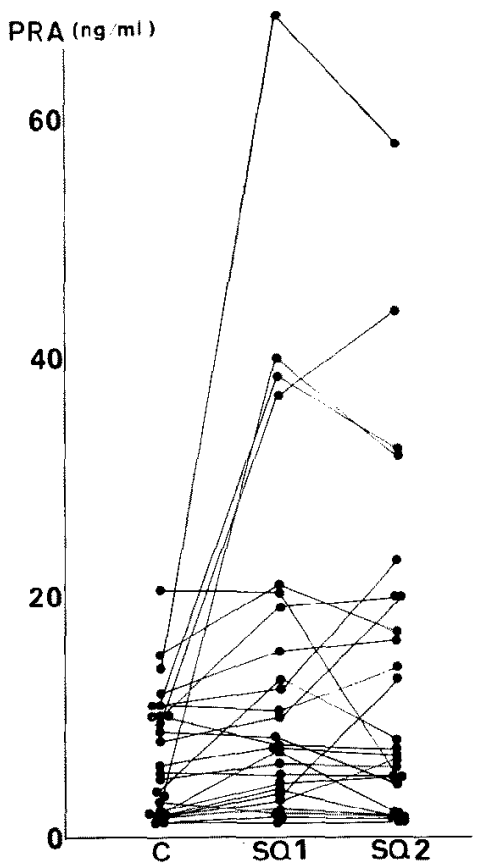

Fig. 2. PRA response to $50 \mathrm{mg}$ of captopril in essential hypertensive patients. Otherwise, the same as Fig. 1. 
Control values of PRA in this group ranged from 2.0 to $21.0 \mathrm{ng} / \mathrm{ml}(7.0 \pm$ $1.0 \mathrm{ng} / \mathrm{ml}$ ). After the administration of captopril, mean value of PRA significantly increased to $14.2 \pm 3.1$ at $\mathrm{SQI}$ and to $15.8 \pm 3.4 \mathrm{ng} / \mathrm{ml}$ at SQ 2, respectively $(\mathrm{p}<0.05)$. Fig. 3 shows the PRA response to captopril in Group III. Control values of PRA in this group ranged from 8.0 to $62.0 \mathrm{ng} / \mathrm{ml}$ $(23.7 \pm 6.3 \mathrm{ng} / \mathrm{ml})$. The mean value was not significantly different from those in Groups I and II. Mean value of PRA at SQI $(71.8 \pm 12.6 \mathrm{ng} / \mathrm{ml})$ and SQ2 $(99.0 \pm 20.7 \mathrm{ng} / \mathrm{ml})$ were significantly higher than the control value $(p<0.01)$. These values were significantly higher than those in Groups I and II at SQI $(15.9 \pm 2.9 \mathrm{ng} / \mathrm{ml}$ in Group I, $14.2 \pm 3.1 \mathrm{ng} / \mathrm{ml}$ in Group II, $\mathrm{p}<0.01)$ as well as at SQ2 $(19.3 \pm 2.1 \mathrm{ng} / \mathrm{ml}$ in Group I, $15.8 \pm 3.4 \mathrm{ng} / \mathrm{ml}$ in Group II, $\mathrm{p}<0.01$ ). Control PRA in 5 of 8 patients of Group III was within the range of those in Groups I and II (Fig. 3). In 3 of 8 patients in Group III, PRA value at SQI was within the range of those in Groups I and II. However, PRA value at SQ2 in 7 to 8 patients in Group III exceeded the range of those in Groups I and II. These 7 patients had either bilateral (Cases 1, 5, and 6) or unilateral (Cases 2, 3, 4, and 7) renal artery stenosis.

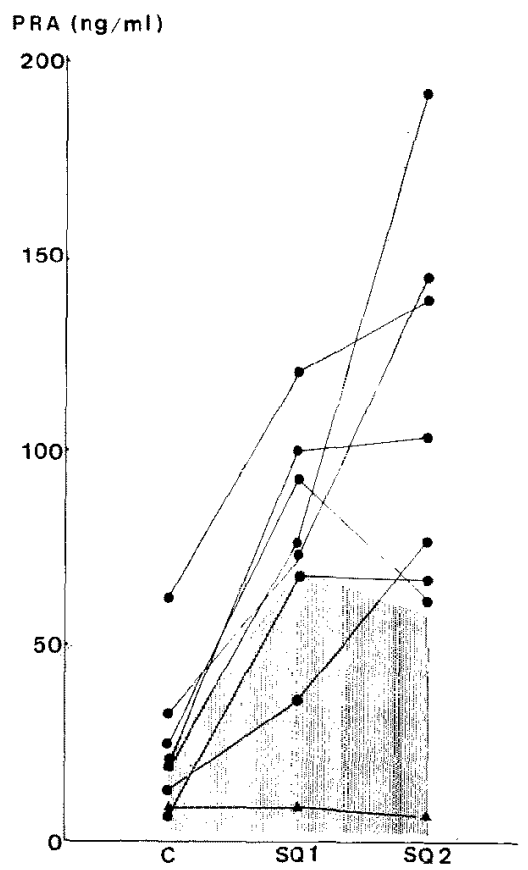

Fig. 3. PRA response to $50 \mathrm{mg}$ of captopril in renovascular hypertensive patients. Solid circles, PRA in each renovascular hypertensive patient. Solid triangle, the Case 8 of Table I. Shaded area, the PRA response to captopril in normotensive subjects and essential hypertensive patients. Otherwise, the same as Fig. 1. 
In only 1 patient (Case 8), captopril resulted in no increase in PRA, and this case had unilateral renal artery stenosis with contralateral renal aplasia. In Group III, the mean increase of PRA (the ratio of PRA 2 hours after

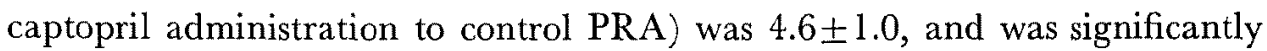
higher than those in other groups $(2.3 \pm 0.5$ in Group I and 2.2 \pm 0.5 in Group II) $(\mathrm{p}<0.05)$. In all patients of Group III except Case 8, PRA values at SQ2 were over twice their respective control values (Fig. 4).

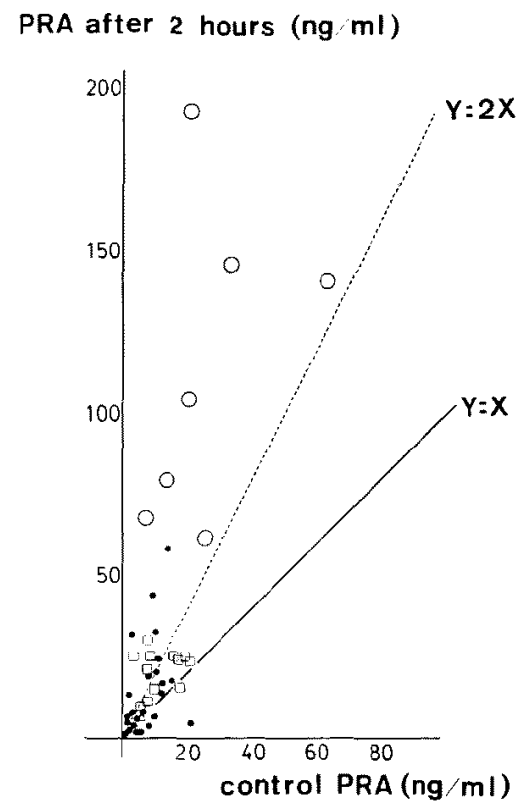

Fig. 4. Relation of control PRA to that 2 hours after captopril administration. Open squares, normotensive subjects. Solid circles, essential hypertensive patients. Open circles, renovascular hypertensive patients. Open triangle, the Case 8 of Table I.

Table II. Effects of Captopril on Mean Arterial Pressure and Pulse Rate

\begin{tabular}{|c|c|c|c|c|c|c|c|c|}
\hline \multirow[t]{2}{*}{ Group No. } & \multicolumn{3}{|c|}{$\mathrm{MAP}(\mathrm{mmHg})$} & \multicolumn{2}{|c|}{$\begin{array}{c}\text { Change in MAP } \\
(\mathrm{mmHg})\end{array}$} & \multicolumn{3}{|c|}{$\begin{array}{l}\text { Pulse Rate } \\
\text { (beats/min) }\end{array}$} \\
\hline & $\mathrm{C}$ & SQ1 & $\mathrm{SQ}^{2}$ & $\mathrm{SQ1-C}$ & SQ2-C & C & SQ1 & $\mathrm{SQ} 2$ \\
\hline Group I & $96 \pm 2$ & $88 \pm 2$ & $90 \pm 2$ & $-8 \pm 2$ & $-8 \pm 3$ & $61 \pm 3$ & $63 \pm 3$ & $65 \pm 3$ \\
\hline Group II & $126 \pm 2^{* * *}$ & $115 \pm 3^{* * *}$ & $112 \pm 3^{* *}$ & $-11 \pm 2$ & $-15 \pm 2$ & $68 \pm 4$ & $67 \pm 4$ & $67 \pm 3$ \\
\hline Group III & $134 \pm 5^{* * *}$ & $117 \pm 8^{*}$ & $118 \pm 7^{* *}$ & $-17 \pm 3$ & $-16 \pm 3$ & $65 \pm 5$ & $67 \pm 4$ & $66 \pm 4$ \\
\hline
\end{tabular}

Abbreviations: $\mathrm{MAP}=$ mean arterial pressure $(\mathrm{mmHg}) ; \mathrm{C}=\mathrm{control} ; \mathrm{SQ} 1=1$ hour after administration of Captopril ; $\mathrm{SQ2}=2$ hours after administration of Captopril. * Change significantly different from Group I $(\mathrm{p}<0.05)$, ** Change significantly different from Group I $(\mathrm{p}<0.01)$, *** Change significantly different from Group I $(p<0.001)$. 

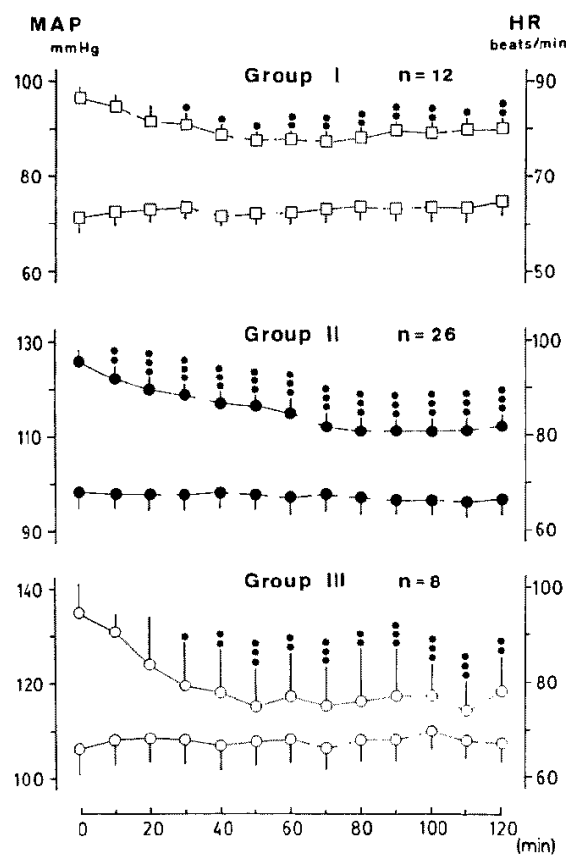

Fig. 5. Effects of captopril on mean arterial pressure (upper trace in each figure) and pulse rate (lower trace in each figure). *Values significantly different from control values $(\mathrm{p}<0.05) ;{ }^{* *} \mathrm{p}<0.01 ; * * * \mathrm{p}<0.001$.
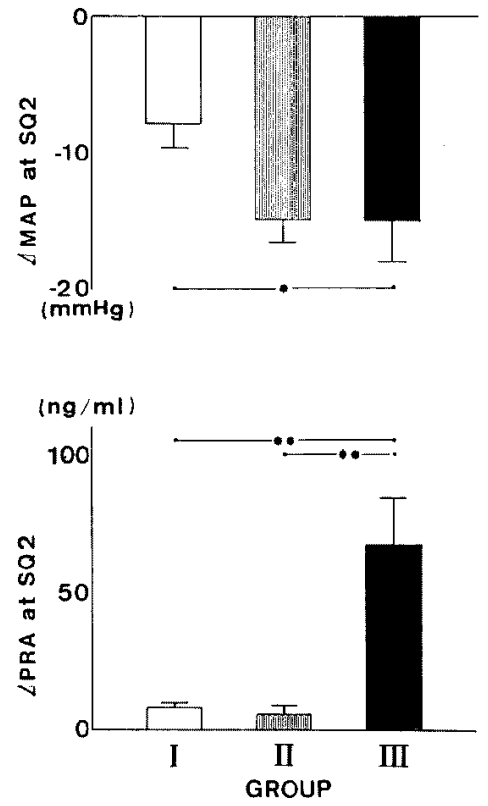

Fig. 6. The changes in mean arterial pressure and TPR in response to captopril at 2 hours after drug administration. Asterisks indicate the statistical significance. ${ }^{*} \mathrm{p}<0.05,{ }^{*} \mathrm{p}<0.01$. 
2. Effects of captopril on MAP and pulse rate

Table II shows the MAP and pulse rate at control period, SQI and SQ2 in each group. The control MAP in Group III was not significantly different from that in Group II. The time course of change in MAP and pulse rate in response to captopril in each group is illustrated in Fig. 5. Captopril induced a significant decrease in MAP in all groups. Pulse rate was not changed by captopril. The increase in PRA in response to captopril at SQ2 in Group III was significantly higher than that in Group II, in spite of no difference in the decrease in MAP at SQ2 between Groups II and III (Fig. 6).

3. Other clinical findings

Urinary sodium excretion at control period in Groups I $(n=8)$, II $(n=11)$, and III $(n=4)$ was $0.30 \pm 0.03,0.27 \pm 0.02$, and $0.31 \pm 0.09 \mathrm{mEq} / \mathrm{min}$, respectively. No significant difference was observed among these values.

\section{Discussion}

This study showed that captopril caused an increase in PRA and a decrease in blood pressure in almost all subjects examined. Our results were consistent with the study of Ferguson et $\mathrm{al}^{9)}$ but not with Sancho et $\mathrm{al}^{\mathbf{8})}$; the latter reported that bolus injection of $0.25 \mathrm{mg} / \mathrm{Kg}$ of SQ 20881, one of the AICEI, produced no increase in PRA in sodium repleted normotensive subjects. Leffan et al $^{14}$ ) reported captopril, on a weight basis, to be about 10 times as potent as parenterally administered SQ 20881. Oral administration of $20 \mathrm{mg}$ of captopril inhibits completely the pressor response to $10 \mathrm{ng} / \mathrm{Kg}$ of angiotensin I for 2.5 hours in human subjects. ${ }^{9}$ ' In contrast, $0.25 \mathrm{mg} / \mathrm{Kg}$ of SQ20881 does not supress completely the pressor effect of $10 \mathrm{ng} /$ $\mathrm{Kg}$ of angiotensin I. ${ }^{15}$ ) Sancho et al observed the changes in PRA for only $30 \mathrm{~min}$, but we followed them for 2 hours. These differences in experimental design may explain the discrepancy between our results and Sancho's.

Various stimulatory maneuvers including upright tilting and adminstration of diuretics ${ }^{3)}$ or vasodilators ${ }^{4}$ ) have been used as a screening test for renovascular hypertension. Even though $63 \%$ of patients with renovascular hypertension had PRA values at rest not different from those in normotensive subjects and essential hypertensive patients, the increase in PRA to captopril administration was much greater in all patients with renovascular hypertension except one than that in normotensive subjects and patients with essential hypertension. Only 1 patient had no response in PRA to captopril. This exceptional patient had unilateral renal artery stenosis with contralateral renal aplasia, an analogous condition to chronic phase of one-kidney type of 
Goldblatt hypertension in animal models in which renin-angiotensin system seemed to be not important. ${ }^{\mathbf{1 B})}$ Such a patient is very rare in renovascular hypertension. Our data, therefore, indicate that the provocation test described here represents an useful screening for detecting renovascular hypertension among hypertensive patients. This conclusion is consistent with the study of Case et al. ${ }^{17)}$ They reported that diagnostic discrimination was greately enhanced by infusion of salarasin or SQ 20881, which elicited marked reactive hyperreninemia in renovascular hypertensive patients.

All the patients with renovascular hypertension showed a hyper-response in renin release to captopril even during the treatment with antihypertensive agents such as propranolol, clonidine, and alphamethyldopa, suggesting that this provocation test may also be used in hypertensive patients under antihypertensive medication. The test can be applied as well in hypertensive patients on an unrestricted sodium diet.

The provocation test presented here should be performed under careful monitoring of blood pressure to avoid too precipitous hypotension not infrequently induced in high renin patients by AICEI. ${ }^{181}$

In the present data, there was no significant difference in the reduction of MAP between renovascular hypertensive group and essential hypertensive group. However, these data do not exclude the possibility that captopril could induce greater reduction of perfusion pressure in the post-stenotic legion of the kidney in renovascular hypertension than in essential hypertension, which, in turn, could produce a greater increase in PRA in the former than in the latter, although the renal perfusion pressure was not measured in this study.

It has been shown that AICEI increases the renin release through its interception of negative short feedback mechanism of the renin release. ${ }^{7,9)}$ Therefore, there is a possibility that this negative short feedback mechanism may be different in renovascular hypertension from that in essential hypertension, thus causing the hyper-response in the renin release to captopril in renovascular hypertension, though there was no proof for this hypothesis.

In summary, the oral administration of $50 \mathrm{mg}$ of captopril produced the hyper-response in the renin release in all patients except one with renovascular hypertension in this study. These data indicate that this provocation test may be useful as a screening procedure for the diagnosis of renovascular hypertension.

\section{References}

1. Cohen EL, Rovner DR, Conn JW: Postural augmentation of plasma renin activity. Importance in diagnosis of renovascular hypertension. JAMA 197: 973, 1966 
2. Strong CG, Hunt JC, Sheps SG, Tucker RM, Bernatz PE: Renal venous renin activity. Enhancement of sensitivity of lateralization by sodium depletion. Am J Cardiol 27: 602, 1971

3. Wallach L, Nyarai I, Dawson KG: Stimulated renin: a screening for hypertension. Arn Intern Med 82: 27, 1975

4. Kaneko Y, Ikeda T, Takeda $\mathrm{T}$, Ueda $\mathrm{H}$ : Renin release during acute reduction of arterial pressure in normotensive subjects and patients with renovascular hypertension. J Clin Invest 46: 705,1967

5. Nielsen I, Nerstrom B, Jacobsen JG, Engell HC: The postural plasma renin response in renovascular hypertension. Acta Med Scand 189: 213, 1971

6. Genest J, Boucher R, DeChamplain J, Veyrat R, Chretien M, Biron P, Tremblay G, Roy P, Cartier P: Studies on the renin-angiotensin system in hypertensive patients. Canad Med Ass J 90: 263, 1964

7. Bing J: Rapid marked increase in plasma renin in rats treated with inhibitors of the renin systcm. Acta Path Microbiol Scand Section A 81 : 376, 1973

8. Sancho J, Re R, Burton J, Barger AC, Haber E: The role of the renin-angiotensin-aldosterone system in cardiovascular homeostasis in normal human subjects. Circulation 53: 400, 1976

9. Ferguson RK, Turini GA, Brunner HR, Gavras H, McKinstry DN: A specific orally active inhibitor of angiotensin-converting enzyme in man. Lancet $1: 775,1977$

10. Re R, Novelline R, Escourrou MT, Athanasoulis C, Burton J, Haber E: Inhibition of angiotensin converting enzyme for diagnosis of renal artery stenosis. New Engl J Med 298: 582, 1978

11. Gavras H, Brunner HR, Turini GA, Kershaw GR, Tifft CP, Cuttelod S, Gavras I, Vukovich RA, McKinstry DN: Antihypertensive effect of the oral angiotensin converting-enzyme inhibitor SQ 14225 in man. New Engl J Med 298: 991, 1978

12. Abe K, Otsuka Y, Saito T, Siang CB, Aoyagi H, Irokawa N, Seino M, Miyazaki S, Miura Y, Ono I, Minai K, Seki K, Kobayashi K, Sato T, Yoshinaga K: Measurement of plasma renin activity by angiotensin I radioimmunoassay. A modification of Haber's method. Jap Circulat J 36: 741, 1972

13. Abe K, Irokawa N, Aoyagi $H$, Memezawa $H$, Yasujima M, Otsuka $Y$, Saito T, Yoshinaga K: Circulating renin in essential hypertension: an evaluation of its significance in the Japanese population. Am Heart J 89: 723, 1975

14. Laffan RJ, Goldberg ME, High JP, Shaeffer TR, Waugh MH, Rubin B: Antihypertensive activity in rats of SQ 14,225, an orally active inhibitor of angiotensin I-converting enzyme. J Pharmacol Exp Ther 204: 281, 1978

15. Collier JG, Robinson BF, Vane JR: Reduction of pressor effects of angiotensin $I$ in man by synthetic nonapeptide (B.P.P. 9a or SQ 20,881) which inhibits converting enzyme. Lancet 1: 72,1973

16. Page $\mathrm{IH}, \mathrm{McCubbin}$ JW (eds): Renal Hypertension. Year Book Medical Publication, Chicago, 1968

17. Case DB, Laragh JH: Reactive hyperreninemia in renovascular hypertension after angiotensin blockade with salarasin or converting enzyme inhibitor. Ann Intern Med 91: 153, 1979

18. Case DB, Atlas SA, Laragh JH, Sealey JE, Sullivan PA, McKinstry DN: Clinical experience with blockade of the renin-angiotensin-aldosterone system by an oral converting-enzyme inhibitor (SQ 14,225, Captopril) in hypertensive patients. Prog Cardiovasc Dis 21: 195, 1978 